\title{
The Effect Remittances Have on the Living Standards of Albanians and on Country's GDP
}

\author{
Dr. Filloreta Madani \\ Vlora "Ismail Qemali", Faculty of Economy \\ L. Pavaresia, Vlore, Albania \\ fcenoll@gmail.com, filloreta.madani@univlora.edu.al
}

Oltiana Muharremi

Lecturer in Accounting and Finance, PhD student University of VIora "Ismail Qemali", Faculty of Economy L. Pavaresia, Vlore, Albania, olta.muharremi@gmail.com

\section{Erald Pelari}

Lecturer in Finance

University of Vlora "Ismail Qemali", Faculty of Economy L. Pavaresia, Vlore, Albania, erald.pelarii@univlora.edu.al

\section{Doi:10.5901/mjss.2013.v4n10p415}

\section{Abstract}

\begin{abstract}
Albania remains one of the countries with the lowest income in Europe. Poverty has forced many people since 1990 to migrate mainly toward Europe in search of a better life. The majority of immigrants have repeatedly sent the savings to their families in Albania. These remittances have significantly improved the Albanians' daily living and simultaneously have a positive impact on the growth of Gross Domestic Product. In recent years, due to the global crisis, there is a decrease in remittances from emigrants and simultaneously an increase in the number of emigrants who are returning home definitely, in order to work and live in Albania. These immigrants, once returned home, are investing their savings mainly in the area of services. In this article we will examine to what extend is the impact of remittances on the lives of Albanians and GDP, as well as factors that have led to an increase or decrease of this impact.
\end{abstract}

Keywords: emigrants, remittances, savings, Albania, income per capita

\section{Introduction}

Albania ranks among the countries with the highest percentage of the labor force living and working abroad. This workforce has played a very important role in supplying the country with foreign currency and stimulated the Albanian economy through remittances to support their families. The beneficial effects of remittances on the Albanian economy during the difficult years of transition are widely known. In 2004, the Bank estimated that the flow of remittances recorded a figure of 13.5 percent of GDP in Albania, three times more than the net foreign direct investment and doubled official development assistance (Official Development Assistance - ODA) to Albania. During the last years, as a result of the global economic crisis or even the combination of this crisis with "A natural cycle", remittances are facing a continual decline. The inflow of remittances, which once marked an amount several times larger than the foreign investment, is fading more and more each year, starting from 2008 and leaving the country a series of questions and uncertainties about what will replace this source. An uncertain analysis and insufficient data has also accompanied the information on the influence that remittances have had into the lives of host families, and to what extent this decline has affected the daily lives of hundreds and thousands of families that benefited from these remittances.

\section{Analysis of migration in time}

Albania has a long history of massive emigration from the Middle Ages. Before the 20th century, the emigration of 
Albanians was characterized by a chaotic movement of the population, not only in the Balkans but also in other countries including Russia and America. Invasions, wars and economic difficulties were the main causes of migration. From the beginning of the 19th century are clearly distinguished three stages of the Albanian emigration:

\subsection{The first stage until 1945}

At the end of the 19th century, Albanian immigrants were concentrated in certain regions of the Ottoman Empire, in Asia Minor, Egypt, Bulgaria and Romania. Data show that in 1880 there were 60,000 in Istanbul, 30,000 in Egypt, in Romania there were 10.000 immigrants and in Bulgaria 2000.

In the early 1900s, the economic potential offered by the U.S.A, Australia, Brazil and Argentina, attracted the attention of many immigrants among them many Albanians. After 1903 emigrants headed to America, Australia, Madagascar, Hindi, Brazil and Argentina. In the following years, especially after 1905, Albanians emigrated to Canada and the USA, starting their long journey not only from Albania, but also from Turkey, Greece and Egypt. Consequently, the largest concentrations of Albanian immigrants in that period are in the U.S.A where the number grew from 30,000 in 1910, up to 80,000 immigrants in 1916. After World War I, the intensity of emigration increased significantly and it was estimated that approximately 111.000 people emigrated toward different countries, mainly in the U.S.A. Taking into consideration the fact that the population of Albania at that time numbered about 900,000 inhabitants, the population in emigration abroad had a considerable percentage, about $12 \%$ of it.

\subsection{Stage II - $1945-1990$}

With the establishment of the communist regime in Albania, emigration always in a smaller size, took a political character. The Albanian government strongly opposed emigration, by all means, taking punitive measures, putting in practice strict political and legal laws, even calling it a crime if someone attempted to leave the country. Despite this existing repression, migration existed in a clandestine form and had a political motive. For a long period of about 45 years, there were about 20,000 immigrants leaving the country.

\subsection{The third stage - after 1990 .}

In the1990, migration abroad has brought basically economic and social changes occurring in Albania. It is estimated that more than 25 percent of Albanians were living abroad. No other country of central and eastern Europe was so much affected by the migration for a short period of time. Russell King claims that Albania can be seen as a laboratory for studying the new migration processes. The data show that starting from 1990, 710.000-1.000.000 Albanians moved out temporarily or to stay there forever. In a country with no more than 3 million inhabitants, this figure is relatively high, so as to attract attention and to justify the researchers. As migration has been chaotic, illegal and unregistered, the figures on this phenomenon are un-specified. This phase is divided into several sub stages:

$>$ The period from 1991-1992 was the because of a destabilizing environment.

> 1992-1996 period was characterized by a relatively called political stability and socio-economic progress. Immigration declined during 1992-1996. The reason was attributable to the improvement of the political stability and socio-economic situation. At the end of 1996 the number of Albanian citizens living abroad amounted to 350.000 people.

$>$ The period from December 1996 - April 1997 was the third wave of emigration. The influx of immigration became more massive in 1997, as a result of the collapse of pyramid schemes and political turmoil that accompanied this event.

> The period from 1998 and onwards, Albanian governments implemented and are implementing a National Stabilization Program.

The trend of migration movement in Albania is presented by a Net migration. By studying this phenomenon, analyzed in five-year terms, beginning from 1976, it is seen that the highest level showed from the years 1991 to 1995, is associated with a significant decrease in the last five years. 
Table 1.1 Net migration in Albania

\begin{tabular}{|c|c|c|c|c|c|c|c|}
\hline 5 -year terms & $\begin{array}{c}1976- \\
1980\end{array}$ & $\begin{array}{c}1981- \\
1985\end{array}$ & $\begin{array}{c}1986- \\
1990\end{array}$ & $\begin{array}{c}1991- \\
1995\end{array}$ & $\begin{array}{c}1996- \\
2000\end{array}$ & $\begin{array}{c}2001- \\
2005\end{array}$ & $\begin{array}{c}2006- \\
2010\end{array}$ \\
\hline $\begin{array}{c}\text { Net } \\
\text { migration }\end{array}$ & -5549 & -4772 & 22871 & -423285 & -270245 & -72243 & -47889 \\
\hline
\end{tabular}

\section{Source: Open Data Albania}

The Falling Net flow of immigrants came mainly from the crisis that two main host countries Greece and Italy suffered, but also from the tendency of Albanians to always return home, in order to live and work in their native country. From a study accomplished in 2003 by llir Gedeshi and Esmeralda Uruci, to the question whether they were ready to return to Albania, 66\% of legal immigrants interviewed answered "Yes", 19.7\% answered "No" and 14.3\% were not sure whether to return in their country or not.

If we compare the Net migration in the years $2005-2010$ with that of other countries in the region, Albania remains in the top list of these countries.

Table 1.2. Net Migration of different Countries' results

Source: ODA 2011

\begin{tabular}{|c|c|}
\hline Country & Net migration \\
\hline Albania & -47889 \\
\hline Bosnia-Herzegovina & -10000 \\
\hline Greece & 154004 \\
\hline Macedonia & 2000 \\
\hline Montenegro & -2508 \\
\hline Serbia & 0 \\
\hline
\end{tabular}

Based on the figures of the above Table, the main host country for Albanians is Greece.

\section{Remittances an important factor in improving the living standards of Albanians}

The model of Albanian emigration after 1990 is described as unique. It is characterized by several features.

Firstly, migration appears as an immediate phenomenon, rattling and explosive, after a 45 year period of isolation. Combined with a powerful internal migration, it results that we have a population moving inside and outside Albania, about half of its population.

Secondly, migration's size, compared to the population of Albania has been bigger than in other countries. Albania is one of the few countries with a quarter of its population in emigration.

Thirdly, migration has played an important role in the survival of the Albanian population, especially in two key moments. In the early 1990s, migration had consequences associated with economic and political changes. During the 1993-1996 periods, economic stability and GDP growth contributed to the reduction of migratory flows. Also remittances, which accounted for 25\% of GDP, made an important contribution to the survival of a large number of Albanians. In 1997, political chaos, economic and social disintegration of firms created by fraudulent schemes, had a negative impact on the welfare of Albanians, so it increased migratory flows again. Albania remains one of the countries with the lowest income per capita in Europe.

Poverty, high unemployment, a long-term transition, the uncertainty of investing, a low level of public services, and these factors are the main reasons for Albanians' migration. Not wanting to dwell on internal migration, since migration flows within the country have been of a considerable size, our study will focus only on migration outside the country (international), and its effects on improving the lives of Albanians. 
Table 2.1. GDP/Capita and Remittances/GDP

\begin{tabular}{|c|c|c|c|}
\hline Years/ Indicators & Growth of GDP & GDP/Capita in \$ & Remittances/GDP \\
\hline 1992 & -0.072 & 211 & $22 \%$ \\
\hline 1993 & 0.096 & 381.5 & $23 \%$ \\
\hline 1994 & 0.094 & 610.8 & $19 \%$ \\
\hline 1995 & 0.089 & 737.8 & $15 \%$ \\
\hline 1996 & 0.091 & 808 & $18 \%$ \\
\hline 1997 & -0.07 & 684 & $12 \%$ \\
\hline 1998 & 0.08 & 906.5 & $15 \%$ \\
\hline 1999 & 0.073 & 1080.9 & $10 \%$ \\
\hline 2000 & 0.078 & 1164 & $14.5 \%$ \\
\hline 2001 & 0.065 & 1357 & $15 \%$ \\
\hline 2002 & 0.047 & 1535 & $15 \%$ \\
\hline 2003 & 0.06 & 1938 & $14 \%$ \\
\hline 2004 & 0.062 & 2336 & $13 \%$ \\
\hline 2005 & 0.055 & 2597 & $12.2 \%$ \\
\hline 2006 & 0.054 & 2854 & $13 \%$ \\
\hline 2007 & 0.06 & 3394 & $12 \%$ \\
\hline 2008 & 0.061 & 4073 & $9 \%$ \\
\hline 2009 & 0.048 & 3765 & $9 \%$ \\
\hline 2010 & 0.038 & 4480 & $8 \%$ \\
\hline 2011 & 0.031 & 4555 & $7 \%$ \\
\hline 2012 & 0.017 & 4156 & $7 \%$ \\
\hline & & &
\end{tabular}

Sources: INSTAT, Bank of Albania,

According to the above table (table 1.1) it is seen an increase in GDP/capita from 1992 up to 2011, followed by a slight decline in 2012. Compared with per capita income in the countries of Europe which for 2012 was $\$ 32,500$, in Albania it is about 8 times lower. A significant impact on - Per capita income has remittances from Albanian emigrants. Since 1991, revenues sent helped Albanians to meet the basic needs of their families.

Receiving remittances through emigration is seen by most Albanians as the most effective way of coping with the country's very difficult economic conditions and ultimately escaping poverty at the individual and household level. Albanian immigrants working abroad have sent home remittances estimated variously (because of the uncertainty of the volume of unrecorded transfers) to be somewhere between $\$ 300$ million and $\$ 1$ billion per annum: the country's major source of external income after aid. Put it another way, the remittances sent by one Albanian migrant were equivalent to 2.5 times the sum of the average wages of all members of a family in 1995.

The majority of the international migrants (69.7\%) send their money in order to meet "the essential needs of the family" and in this case we have to do with the constant remittance, used completely for consumption. Whereas the additional remittances related to "the furnishing of the house" are sent only by $29.9 \%$ of international migrants, 9.4 per cent of migrants send remittances for investment in their homeland, and only $18 \%$ of migrants send remittances for the "purchase and construction of a house".

\subsection{The source countries of Albania's remittances}

The two host countries with the largest numbers of Albanians were Italy and Greece. As shown on table 2.2, beside them are ranked some other places that have received a considerable number of Albanian emigrants. Of course, the main income from remittances came from Italy and Greece. 
Table 2.2. The number of Albanians migrating after 1990, according to their host countries

\begin{tabular}{|c|c|}
\hline Host countries & Nr.of emigrants \\
\hline Greece & 600,000 \\
\hline Italy & 250,000 \\
\hline Germany & 15,000 \\
\hline U:S:A & 150,000 \\
\hline Great Britain & 50,000 \\
\hline Belgium & 5,000 \\
\hline France & 2,000 \\
\hline Canada & 11,500 \\
\hline Switzerland & 1,500 \\
\hline Austria & 2,000 \\
\hline Netherland & 1,000 \\
\hline Turkey & 5,000 \\
\hline TOTAL & $1,193,000$ \\
\hline
\end{tabular}

Source: Albanian government and IOM, "National Strategy on Migration", Tirana 2005

The Income from remittances for 2009 (according to World Bank, Migration and Remittances Factbook 2011) was 11\%. The main countries of remittances are Greece, Italy, United States of America, Macedonia, Germany and Canada. These six countries have the major share of remittances to Albania as it constitutes $98 \%$ of the total. Other countries constitute a very low percentage, only $2 \%$ of the total, however it is interesting to see foreign countries from which our citizens send their earnings.

Table 2.3. The value of remittances in Euro \& USD for 2011

\section{Source: World Bank}

\begin{tabular}{|l|c|c|c|}
\hline Host countries & USD & Euro & In $\%$ \\
\hline Canada & 10.30 & 5.93 & 0.91 \\
\hline Germany & 13.74 & 7.92 & 1.21 \\
\hline Macedonia & 64.57 & 37.21 & 5.70 \\
\hline U.S.A & 74.47 & 42.92 & 6.57 \\
\hline Italy & 431.54 & 248.71 & 38.09 \\
\hline Greece & 538.31 & 310.24 & 47.51 \\
\hline Total & $\mathbf{1 , 1 3 2 . 9 2}$ & $\mathbf{6 5 2 . 9 4}$ & 100.00 \\
\hline
\end{tabular}

Greece and Italy are the two main countries where Albanian citizens have emigrated, they live and work there. Greece is the country with the highest values of incoming remittances. The value of shipments marks EUR 310243000 (three hundred and ten million two hundred and forty-three thousand Euros) and constitutes $47 \%$ of the total. After Greece, Italy has the highest value of remittances to Albania with a shipment of 248710000 EUR shipment (two hundred forty-eight thousand seven hundred and ten thousand Euros).

\subsection{Correlative links between GDP and migration flows}

There is a correlative link between economic development of the Albanian economy and migration flows. The improving of Albanian economy has a positive impact on reducing migration flows. In principle, revenue growth should be influenced by expectations about developments in the economy. Forecasts for growth in the price level and exchange rate depreciation should be associated with higher levels of interest rate and will encourage a greater entry of foreign currency from immigration. In the years 1994 - 1996, the phenomenon of remittances is observed; we have a withdrawal of foreign currency revenues from the domestic pyramid, reaching the highest level in 1996. 1997 and 1999 recorded a decrease of these transfers, respectively, as a result of the 1997 crisis, the collapse of pyramid schemes and the Kosovo crisis.

According Papanagos \& others (2008), migration from Albania slowed significantly after 2000. This downward trend is a consequence of several factors, the most important is the improvement of economic conditions in the country, 
as it can be understood by the indicators of GDP growth. Between 1998 and 2008, the real growth rate of GDP averaged $7 \%$ per year. On the other hand effective control of borders (notably of Italy and Greece) and the fact that many Albanians have already migrated, has contributed to the decline of migration .2.2

Still Albanians tend to migrate abroad. According to a study made by ETF (2007), 17.8\% of the population observed, has the real intention and possibility to migrate.

Relying on the Classification of S. Wahba11, who makes reference to Giudici12 (1998), we can distinguish four Types of remittances:

1. Potential remittances, which represent the total savings of the emigrants. This can be calculated by subtracting the personal necessary expenditures incurred in the country of emigration from the incomes.

2. Constant remittances, which imply the minimum income that the emigrant sends to his family in the country of birth, intended to cover the cost of daily necessities.

3. Additional remittances, which represent extra income over the regular amount sent by the emigrant. This is not used to meet the most acute needs of the family, but for investments in factual or financial undertakings.

4. The spared remittances, representing the amount of savings that the emigrant doesn't intend to make as a remittance, but prefers to invest in the country of emigration.

Having marked with:

$Y=$ the income of the emigrant in the country of emigration

$\mathrm{C}=$ the indispensable consumption of the emigrant

$\mathrm{C}=$ the daily necessities of the emigrant's family

$\mathrm{S}=$ emigrant's savings

We can write: $Y=C+C+S$

We can sum up the different types of remittances as follows:

$\mathrm{R}=\mathrm{c}+\mathrm{aS}+(1-\mathrm{a}) \mathrm{S}=\mathrm{c}+\mathrm{S}$

$\mathrm{R}=$ potential remittances, $\mathrm{C}=$ constant remittances, $\mathrm{a}=$ emigrant's tendency to send the savings

$\mathrm{aS}=$ additional remittances

$(c+a S)=$ dispatched remittances, and $(1-a) S=$ spared remittances

The amount of dispatched remittances from the emigrants to the country of origin, is determined by a group of factors like:

- The number of employees that have emigrated and are working abroad.

- The structure of emigrants according to age, civil status and family unification, scale of qualification, neighborhood with the country of emigration, legalization, etc.

- Labor conditions also have a strong impact on remittances. The key elements that exert influence in this case are the wage level, which changes according to the country of emigration, the type of work, facilities created by the local employers for the emigrants, etc.

- The amount of remittances depends also on the security, speed and ease of transferring money to the homeland.

- Political, economic and social changes occurring in the country of origin and destination, also have a great impact on the quantity of remittances transferred.

What has recently been noted is the significant decrease of the 'a-factor = immigrant's Tendency to send the Savings". Notwithstanding this decreasing trend, we believe that for many years remittances will play an important role in economic indicators in Albania.

\subsection{The relationship GDP - remittances}

Net remittances transfers without counter to or from country, are an integral part of the income and indirectly part of GDP. During the period of 1991-2000, immigrants' remittances have been increasing and have represented about 10-22 per cent of GDP respectively. Pursuant to Bank of Albania estimated: they reached to about USD 620 million in 2001, or about 15 per cent of GDP13, in USD 150 million or about 22 Percent of GDP were in 1992. (Gedeshi, Uruci, 2003).

During 2002-2012 the position of remittances toward GDP increased until 2007 and declined in the coming period. The best year resulted 2007, where remittances have reached a 952 million value. Gross Domestic Product this year has been seven billion eight hundred and twenty nine million, a considerable figure compared to 2006 when GDP was five billion eight hundred and seventy-six million. The lowest remittances during this decade have been in 2011 with 665 million shipments. The years 2003-2004 resulted in a constant value of GDP -in a value of 774 million. 
Chart 2.1. Remittances chart and Gross Domestic Product

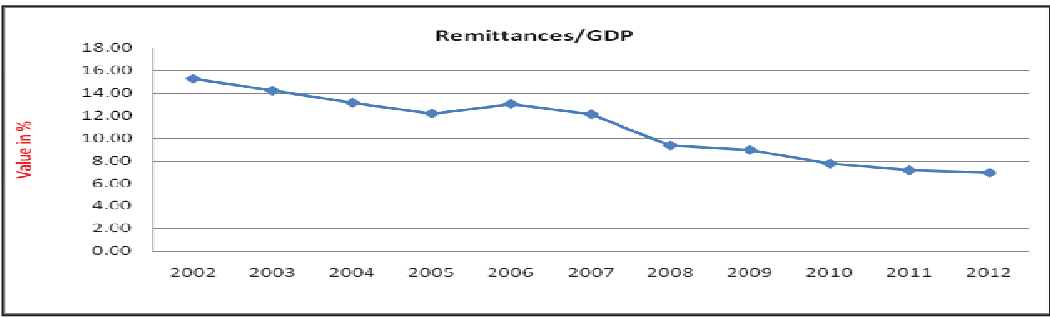

Source: Annual Reports of the Bank of Albania.

\subsection{The link between remittances and exports}

Remittances are shipments of immigrants working abroad, while exports represent the value of I goods and services sold or performed abroad. Both of these values are important to the national economy and the standards of living in the country. In 2001, remittances were about twice higher than foreign currency income on exports. Remittances have also played an important role in financing imports and covering the trade deficit. Important was their role even for maintaining the eventual Domestic currency exchange rate and for fast development of services and the Sectors of Construction. Thus, they have positively impacted on the macroeconomic Stability of the country. In the time span of ten years 2002 2012, the positioning of these two values presented is really interesting. In the time frame 2002 - 2007 remittances stayed higher than exports showing a weak economy based on manufacturing shipments market share of nationals working abroad. In 2008 this difference varies and this is the first year in which the value of goods and services sold abroad is higher than the value of the domestic economy obtained money from remittances. The difference was shaken again in 2009 where remittances recorded a higher value than export revenues. The last three years indicate an increase in the value of exports by creating a progressive margin export remittances towards a positive value.

Chart 2.2. The link between remittances and exports

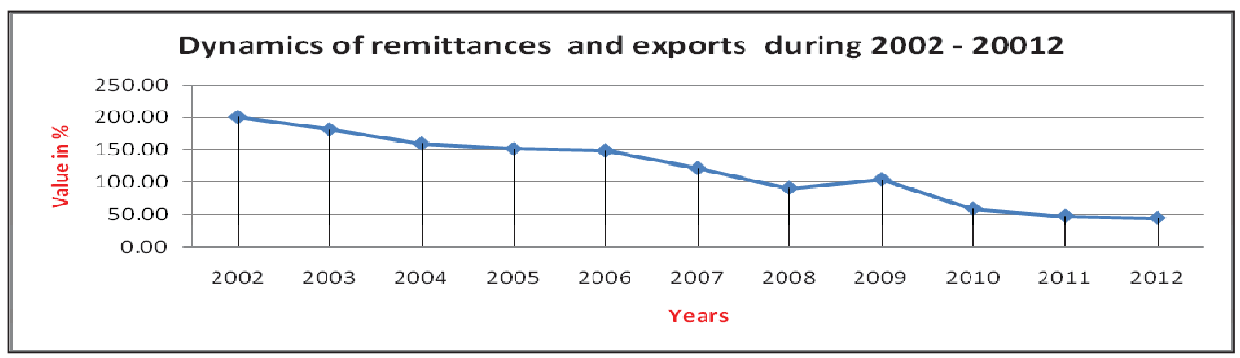

Source: Bank of Albania

In the last three years (2010-2012) exports are much larger in value compared with remittances. During these three years, remittances have been almost constant, while exports increased by one billion two hundred and seventy million in 2010 to one billion five hundred and sixty-two million Euros in 2012. The comparison of remittances and exports, and the ratio between the two values, aims to investigate the trend of the domestic economy and contributing to the national balance of payments. If in 2002, remittances were double the value of exports in 2012 this value of remittances from abroad constituted only $50 \%$ of the value of exports. This marked difference is based on the value of exports increased over the past ten years.

\subsection{Linking Remittances - Foreign Direct Investment}

Both these indicators are inflows of balance of payments and are two important indicators for the growth of national 
economies. Foreign direct investment includes investments of foreign individuals and institutions in the local economy, if the investment makes the investor own more than $10 \%$ of the equity of an enterprise. During this three-year the value of FDI is higher than the value of Remittances. 2010 recorded the highest difference between the value of shipments of migrant remittances and the value of foreign direct investment. In this year 690 million Euro mark remittances and FDI are worth 789 million Euros. This is the first year when remittances fall below the value of foreign direct investment.

Chart 2.3. Linking Remittances - Foreign Direct Investment

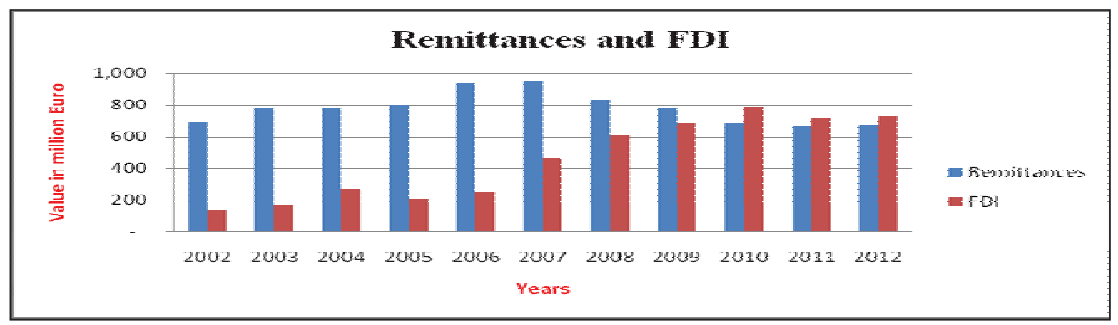

Source: Bank of Albania

This difference in favor of the value of foreign investments is due to the fall in remittances and also due to the increase in the value of foreign direct investment. The difference is reduced in the next two years- 2011 and 2012. In these two years the value of foreign direct investment has fallen respectively 717 and 727 million Euros. Even though, in values higher than the value of remittances, the performance of the last two years for foreign direct investment again demonstrates that the Albanian economy still relies on sustainable delivery of Albanians working abroad.

Over a longer period of ten years 2002-2012, the ratio of these two values appears more interesting. Years 2006 2010 are the years with a progressive increase of the value of foreign direct investment. This time period marks a positive moment for the local economy. However the value of remittances is also considerable, variable in a decade, from 665 million Euros the year with the lowest value to 952 million Euros with the year with the best value. This percentage has been decreasing, proving once again the fact that if in the first decade remittances helped to develop the economy, occupying a very important part of GDP, the second part of this situation is changing in favor of FDI.

\subsection{The current state of migration}

According to the data of the Albanian Centre for Competitiveness and International Trade, during the first half of 2013, 18 to $22 \%$ of emigrants are returned to Albania, which is equivalent to 180,000 people. The main reasons are: unemployment, higher taxes and rising costs of living in Greece, which have made living there impossible. The same phenomenon is not seen in the next Albanians' host country, Italy.

It remains a concern how these immigrants, who have had an average of 10 to 15 years away from their place of birth, will adapt to the life in Albania.

This wave of immigrants is expected to exert strong pressure on public services in the country and especially in Education and health services.

\section{Conclusions and findings}

1. Albanian families use the remittances for the most basic expenses such as food and health services. The reducing of remittances in the recent years is worrying because this fact will worsen the quality of life of these families.

2. Starting from 2008 there has been a significant deterioration of remittances to Albania, it has happened both in quantity as well as in percentage of GDP.

3. Remittances in Albania serve to regulate the balance of payments, it is clear that this way of balancing is not sustainable in the long term. For this reason it is necessary to develop and implement incentive policies that 
will affect the growth of foreign direct investment (FDI) and export growth, as two other components of the balance of payments. This will affect the stability of the economy.

4. The negative effects of shipments' downturn mostly fall on poor families. This requires a new focus on public policies that will bring poverty alleviation, especially it will improve social assistance schemes.

5. The returning home of about 180,000 immigrants, because of the Greek crisis, requires implementing policies that promote the growth of employment. In the case of immigrants and their families a great help to give would be undertaking particular policies that promote education and professional development.

\section{References}

Bajraba Costa, Looking beyond borders, August 2004

Fan Noli, the second act, Pristina, 1988, p. 307

Giudici C., Les effects economiques des migrations: les remises, Paper presented in the workshop "Agriculture, migrations and rural developments in Albania, Bulgaria and FYR of Macedonia", PHARE ACE Programme, P96-6070-R, Athens, October,1998

INSTAT, Preliminary Results of the Populatin and Housing Census 2001.

IOM. MPCSSHB, 2006, Strategjia Kombetare për Migracionin. (National strategy for migration)

King R., Across the sea and over the mountains: documenting Albanian Migration, School of - European Studies, University of Sussex, 2003-11-21

King Russell and Vullnetari Julie, December 2003, Migration and Development in Albania, Sussex Centre for Migration Research Nicola Mai, 2007,Albania migration: demographic and other transformations.

Papapanagos, H. and Sanfey, P., 'Albanian Emigration: Intentions versus Actual Behavior', working paper, 2002.5.

Papailias, P. 2003. "'Money of Kurbet is Money of Blood": The Making of a "Hero" of Migration at the Greek-Albanian Border', Journal of Ethnic and Migration Studies, 29(6): 1059-1078.

Papapaganos, H. and P. Sanfey 2001. 'Intention to Emigrate in Transition Countries: The Case of Albania', Journal of Population Economics, 14(3): 491-504.

Ragaru, N. 2002. 'The Albanian-American Community in the United States: The Story of a Diaspora'. Paper presented at the International Conference on 'Albanian Migration and New Tran nationalisms', University of Sussex, 6-7 September 2002.

Tirta, M. 1999. Migrime të Shqiptarëve. Tirana: Shkenca (Ethnografia Shqiptare 18).

UNDP2002. Albania Human Development Report 2002. Tirana: UNDP.

UNFPA 1991, Albania Report. New York: UN Population Division. 